Western University Scholarship@Western

Centre for the Study of International Economic Centre for the Study of International Economic

Relations Working Papers

Relations

1983

\title{
New Products and the Factor Content of International Trade
}

Richard A. Brecher

Ehsan U. Choudhri

Follow this and additional works at: https://ir.lib.uwo.ca/economicscsier_wp

Part of the Economics Commons

Citation of this paper:

Brecher, Richard A., Ehsan U. Choudhri. "New Products and the Factor Content of International Trade." Centre for the Study of International Economic Relations Working Papers, 8312C. London, ON: Department of Economics., University of Western Ontario (1983). 
CENTRE FOR THE STUDY OF INTERNATIONAL ECONOMIC RELATIONS

WORKING PAPER NO. $8312 \mathrm{C}$

NEW PRODUCTS AND THE FACTOR CONTENT OF INTERNATIONAL TRADE

Richard A. Brecher and

Ehsan U. Choudhri
Depariment of Economics Library

$$
\text { (n) } 71983
$$

University of Western Ontario

This paper contains preliminary findings from research work still in progress and should not be quoted without prior approval of the author.

DEPARTMENT OF ECONOMICS

UNIVERSITY OF WESTERN ONTARIO

LONDON, CANADA

N6A 5 C 2 
NEW PRODUCTS AND THE FACTOR CONTENT OF INTERINATIONAL TRADE*

Richard A. Brecher and Ehsan U. Choudhri

\author{
Department of Economics \\ Carleton University
}

May 1983

Department of Economics Library

JIN 71983

University of Westem Ontario

*The present paper is a condensed version of our (1982c) earlier manuscript, which provides additional details. We gratefully acknowledge helpful comments and suggestions from Jagdish N. Bhagwati, Alan V. Deardorff, Robert C. Feenstra, Jacob A. Frenkel and an anonymous referee. 


\section{Introduction}

Vernon's (1966) product-cycle hypothesis and related analyses [e.g., Hufbauer (1966, 1970), Kravis (1956) and Posner (1961)] have stimulated considerable interest in the role of "new products" for determining the factor content of international commodity trade, and for understanding the Leontief Paradox. While there is a substantial literature emphasizing the empirical importance of these goods, they still need to be incorporated formally into the standard factor-content theory of world trade, in the tradition of Melvin (1968) and Vanek (1968).

To address this need, the present paper extends the multi-commodity twoinput version of the Heckscher-Ohlin model to include new products, defined here as goods whose technology is available in only one country. In section II, the extended model is used to re-examine the implications of relative factor abundance for the capital and labour content of world trade. As explained in Section III, the presence of new products might in principle resolve the Ieontief Paradox under certain specific conditions.

\section{The Extended Model}

Start with the standard Heckscher-Ohlin model of a two-country two-factor world, in which capital and labour are used to produce any number of "old products", defined here as goods whose technology is identical internationally. Now, extend this model to incorporate one or more new products (defined above). As usual, assume constant returns to scale in production, absence of factor-intensity reversals, identical homothetic tastes for the home and foreign countries, international immobility of capital and labour, perfect competition, and free trade.

To highlight certain stylized features of Vernons's (1966) discussion, we restrict our attention to the interesting case in which the following three assumptions also hold. First, the (physically) capital-abundant country is the sole producer of all new goods. ${ }^{I}$ second, this country has a higher wage-rental ratio 
than the rest of the world. ${ }^{2}$ Third, new products are labour intensive in relation to old goods, when the two types of commodities are compared at the same wage-rental ratio. 3

Ietting the home country be the relatively capital-abundant one,

$$
\overline{\mathrm{K}} / \overline{\mathrm{K}}^{\mathrm{W}}>\overline{\mathrm{L}} / \overline{\mathrm{L}}^{\mathrm{W}}
$$

where $\bar{K}$ and $\bar{L}$ represent the fixed endowments of capital and labour, respectively, for this economy; while $\overline{\mathrm{K}}^{\mathrm{W}}$ and $\overline{\mathrm{L}}^{\mathrm{W}}$ denote the corresponding endowments for the world as a whole. As we shall now proceed to show, predictions about the factor content of international trade in the extended (unlike the standard) model depend on whether any (old) good is produced in common by both countries. 4

To dispense first with the simpler case, begin by supposing that there is no "common product", defined here as a good produced in both countries. In this case, the factor requirements per dollar's worth of each good are unique in world production and hence consumption. Therefore, the presence of new commodities does nothing to upset the following condition used by Leamer (1980):

$$
F_{c}=\alpha \bar{F}^{W}, F=K, L \text {, }
$$

where $K_{c}$ and $I_{c}$ are the total amounts of capital and labour, respectively, embodied in home consumption; and $\alpha$ is the home country's relative share of total world expenditure.

From (I) and (2), $L_{C} \sqrt{\mathrm{L}}>K_{c} / \bar{K}$ or, equivalently, $K_{T} / \bar{K}>I_{T} / \bar{L}$; where $K_{T}\left(\equiv \bar{K}-K_{c}\right)$ and $I_{T}\left(\equiv \bar{L}-L_{c}\right)$ denote net exports of capital and labour, respectively, embodied in the commodity trade of the home country. Thus, despite our introduction of new products, there is not yet any violation of Vanek's (1968) well-known proposition concerning the factor-content "chain of comparative advantage", which may be expressed generally as follows: Ranking the factors of a country (say the home one) by relative domestic abundance $\left(\bar{F} / \bar{F}^{\mathrm{W}}\right)$ is the same as ranking them by 
relative net exports $\left(F_{T} / \bar{F}\right) \cdot 5$

The situation changes dramatically, however, as we now introduce a common good ${ }^{6}$, produced with factor requirements that differ between countries (given the international divergence in wage-rental ratios). To preserve (2) in the face of these differences, we would clearly need to have equality of $\theta$ and $\theta^{*}$, which respectively denote the proportions of home and foreign consumption of the common good met from home production. Given the conventional assumption that international trade of each (homogeneous) good is unidirectional, however, it is easy to see that $\theta>\theta *$ unambiguous $1 \mathrm{y} .{ }^{7}$ Thus, home consumption of the common good is definitely biased in favour of home production, which (per dollar's worth of output) uses more capital and less labour than foreign production, given that the wage-rental ratio is higher at home than abroad. Consequently, (2) must be replaced by

$$
F_{c}=\beta^{F} \alpha \bar{F}^{W}, F=K, I,
$$

where $\beta^{K}>1>\beta^{I}$ necessarily. ${ }^{8}$ If $\beta^{K}$ is sufficiently greater than $\beta^{L}$, then from (I) and ( $2^{\prime}$ ) we now can have $\mathrm{L}_{\mathrm{T}} / \overline{\mathrm{L}}>\mathrm{K}_{\mathrm{T}} / \overline{\mathrm{K}}$, in clear violation of the chain proposition stated above.

The possibility of this violation is illustrated dramatically (with $\mathrm{I}_{\mathrm{T}}>0>\mathrm{K}_{\mathrm{T}}$ ) in Figure $I$ for the case of balanced commodity trade. In this diagram, HH' and FF' are unit isocost lines in the home and foreign countries, respectively. The unit-value isoquants 1,2 and 3 represent a dollar's worth of output for old goods $I$ and 2 and new good 3. (For now, no other commodities exist, and hence isoquant 4 should be ignored.) The slopes of (undrawn) rays $O E$ and (flatter) OD give, respectively, the capital-labour endowment ratios of the home and foreign countries. For simplicity, (common) good 1 is not traded internationally. ${ }^{9}$ since point $N$ lies southeast of point $B$, every dollar's worth of home exports (of good 3) uses more labour and less capital than every equal-valued 
gmount of foreign exports (of good 2). Thus, the home country is a net exporter of labour and importer of capital!

It is important to stress that the relative labour intensity of new products is not itself enough to ensure this violation of the chain proposition. Given their presence, the crucial issue is the magnitude of biases $\left(\beta^{\mathrm{K}}\right.$ and $\beta^{\mathrm{L}}$ ) created by common-good production. Only if these biases are sufficiently great can the chain be reversed as in the above example.

\section{The Leontief Paradox}

Although Leamer (1980) has shed considerable light on the Leontief Paradox, Ieontief's (1954) data for the United States include some features which are not satisfactorily explained in the model with only old products. For instance, as Brecher and Choudhri (1982b) have shown, it was paradoxical that $I_{T}>0$ (despite $\overline{\mathrm{L}} / \overline{\mathrm{L}}^{\mathrm{W}}<\alpha$ ) for the U.S. Also, since Leontief's estimates show U.S. capital (labour) requirements per million dollars to be less (greater) for exports than imports, his figures suggest the paradox that $I_{T}>0>K_{T}$ if commodity trade were balanced. ${ }^{10}$ As is clear from Section II above, an explanation of these paradoxical findings is possible if new products are incorporated into the model. In this case, the labour bias $\left(\beta^{L}\right)$ due to common-good production might be sufficiently pronounced to yield $\overline{\mathrm{I}}>\beta^{\mathrm{L}} \alpha \overline{\mathrm{L}}^{-W}$ for the U.S., thereby implying that $I_{T}>0\left[\right.$ in view of $\left.\left(2^{\prime}\right)\right]$. Also, the capital bias $\left(\beta^{\mathrm{K}}\right)$ for the U.S. might at the same time be great enough to cause $K_{T}<0$ under balanced commodity trade (as illustrated above in Figure 1 ). Thus, the presence of new products can in principle explain an apparent failure of the Heckscher-Ohlin Theorem in its Melvin (1968)-Vanek (1968) factorcontent version, which predicts that $K_{T}>0>I_{T}$ if commodity trade is balanced. Finally, with (but not without) new products we can intriguingly have the following new possibility: The Ieontief Paradox might simply be a measurement error, 
due to Leontief's (1954) method of using home rather than foreign requirements to estimate the factor content of U.S. imports. ${ }^{11}$ Even when $K_{T}>0>I_{T}$, we may observe $\hat{\mathrm{I}}_{\mathrm{T}}>0>\hat{\mathrm{K}}_{\mathrm{T}}$, where a circumflex over a variable indicates the Leontief estimate (based wholly on home requirements of factors). Although this combination of true and estimated outcomes cannot arise when all goods are old, the following example illustrates the possibility of this combination in the presence of new products.

In Figure I, now assume that goods 4 (with unit-value isoquant 4) and 1 are the world's only commodities. (Thus, isoquants 2 and 3 should now be ignored.) The home country produces and exports (new) product 4, while producing and importing good 1. [Note that $O A^{\prime}$ (not drawn) is now the foreign endowment ray, representing a lower capital-labour ratio than the domestic endowment ray, which is still OE (not drawn).] Since point $C$ lies northwest of point $A^{\prime}$, balanced commodity trade would imply $K_{T}>0>I_{T^{*}}$ At the same time, however, $\hat{L}_{T}>0>\hat{K}_{T}$, because point $C$ lies southeast of point A (which provides the Ieontief estimates of the true requirements given by point $A^{\prime}$ ).

As suggested by this example, the home country could appear to be exporting capital and importing labour even when the opposite pattern of factor trade actually holds. For this possible outcome to be consistent with Ieontief's (1954) data, his estimates of labour and capital content per million dollars would have to be only $7 \%$ below and $20 \%$ above the true levels, respectively. Although detailed verification of such a possibility would be beyond the scope of the present paper, some readily available data (for labour) suggests that the actual bias may well be considerably greater. 12 


\section{Footnotes}

1. See also Krugman (1979) for a (one-factor) model of trade between an innovating "North" and on imitating "South".

2. If factor prices were assumed to remain equal between countries, introducing new products would not essentially affect the standard factor-content theorems of international trade, as explained by Vanek and Bertrand (1971). See also footnote 3 below.

3. Thus, as could readily be shown, the capital-abundant country cannot have a lower wage-rental ratio than the rest of the world.

4. On the lack of such dependence when new products are absent, see Brecher and Choudhri (1982a).

5. More could be said if balanced commodity trade were assumed. Then, letting $P_{K}$ and $P_{I}$ denote home (unequal to foreign) prices of capital and labour, respectively, we could readily show that $P_{K} K_{T}+P_{L} L_{T}<0$ given cost minimization. From this result and the chain proposition stated above, $I_{T}<0$. We could simultaneously have $\mathrm{K}_{\mathrm{T}}<0$, intuitively because the home country's exports of new products embody a "technology content", which might be exchanging internationally for both a capital and labour content.

6. Only one such good is possible in the two-factor free-trade model with international factor-price differences, as noted by Deardorff (1979). The present analysis extends readily, however, to any number of common products in the presence of production tax-cum-subsidies in favour of import-competing goods.

7. As the home country is an exporter, nontrader or importer of the common product, we have $\theta=1>\theta^{*}>0, \theta=1>\theta^{*}=0$ or $1>\theta>0=\theta^{*}$, respectively. 
8. As could readily be shown, $\beta^{F}-I=\left(\theta-\theta^{*}\right)\left(a_{F}-\frac{a_{F}^{*}}{F} C^{*} / \bar{F}^{W}, F=K\right.$, L; where $a_{K}$ and $a_{\mathrm{L}}$ are the inputs of capital and labour, respectively, per dollar's worth of home output of the common good; $a_{K}^{*}$ and $a_{L}^{*}$ are the corresponding requirements in the foreign country; and $C^{*}$ is foreign consumption of the cormon good. If additional common goods were admitted in accordance with footnote 6 , we would still have $\beta^{\mathrm{K}}>I>\beta^{\mathrm{I}}$.

9. This simplification was suggested to us by Alan V. Deardorff, who noted that $A E / A N=A^{\prime} D / A^{\prime} B$ in this case, since the relative share of (nontraded) good $I$ in national income must be the same for both countries (given balanced commodity trade and equal homothetic tastes).

10. Admittedly, a move to balanced commodity trade (from the position of surplus in Leontief's data) could have changed the commodity composition of U.S. trade, and thus might have altered the factor content per million dollars of exports and imports. There is no reason to expect, however, that such a change would have reversed the signs of $K_{T}$ and $I_{T} \cdot$ Baldwin (1971) has, in fact, estimated the factor content of U.S. trade for a period in which this country's trade surplus was considerably smaller than in Ieontief's period. Baldwin's estimates confirm that, per million dollars, the U.S. was a net exporter of labour and importer of capital.

11. On the inappropriateness of this estimation procedure when factor prices differ internationally, see Deardorff (1982). Nevertheless, without new products, Brecher and Choudhri's (1982a) proof that $K_{T}>0>I_{T}$ is qualitatively unaffected if factor requirements of home importables are estimated (à la Ieontief) by the points where isoquants for such goods touch the unit isocost line of the home country.

12. For evidence on differences in (direct) labour coefficients between the U.S. and three other countries (India, Japan and the United Kingdom), see Lary's (1968, appendix B) detailed bilateral comparisons of value added per employee. 


\section{References}

Baldwin, Robert E., "Determinants of the Commodity Structure of U.S. Trade", American Economic Review 61 (March 1971), 126-46.

Brecher, Richard A. and Ehsan U. Choudhri, "The Factor Content of International

Trade without Factor-Price Equalization", Journal of International Economics 12 (May 1982), 277-83. (a)

Brecher, Richard A. and Ehsan U. Choudhri, "The Leontief Paradox, Continued", Journal of Political Economy 90 (August 1982), 820-3. (b)

Brecher, Richard A. and Ehsan U. Choudhri, "New Products and the Factor Content of International Trade", unpublished manuscript, Carleton Economic Papers, No. 82-20 (November 1982). (c)

Deardorff, Alan V., "Weak Links in the Chain of Comparative Advantage", Journal of International Economics 9 (May 1979), 179-209.

Deardorff, Alan V., "The General Validity of the Heckscher-Ohlin Theorem", American Economic Review 72 (September 1982), 683-94.

Hufbauer, G.C., Synthetic Materials and the Theory of International Trade.

Cambridge, Massachusetts: Harvard University Press, 1966.

Hufbauer, G.C., "The Impact of National Characteristics and Technology on the Commodity Composition of Trade in Manufactured Goods", in The Technology

Factor in International Trade, edited by Raymond Vernon. New York: Columbia University Press (for National Bureau of Economic Research), 1970.

Kravis, I.B., "'Availability' and Other Influences on the Commodity Composition of Trade", Journal of Political Economy 64 (April 1956), 143-55.

Krugman, Paul, "A Model of Innovation, Technology Transfer, and the World Distribution of Income", Journal of Political Economy 87 (April 1979), 253-66. 
Lary, Hal B., Imports of Manufactures from Less Developed Countries. New York: Columbia University Press (for National Bureau of Economic Research), 1968. Leamer, Edward E., "The Leontief Paradox, Reconsidered", Journal of Political Economy 88 (June 1980), 495-503.

Leontief, Wassily, "Domestic Production and Foreign Trade: The American Capital Position Re-Examined", Economia Internazionale 7 (February 1954), 9-38.

First appeared in Proceedings of the American Philosophical Society 97 (September 1953), 332-49. Melvin, James R., "Production and Trade with Two Factors and Three Goods", American Economic Review 58 (1968), 1249-68.

Posner, M.V., "International Trade and Technical Change", Oxford Economic Papers 13 (October 1961), 323-41.

Vanek, Jaroslav, "The Factor Proportions Theory: The N-Factor Case", Kyklos 21 (1968), 749-56.

Vanek, Jaroslav and Trent J. Bertrand, "Trade and Factor Prices in a Nulti-Commodity World", in Trade, Balance of Payments and Growth: Papers in International Economics in Honor of Charles P. Kindleberger, edited by Jagdish N. Bhagwati et al. Amsterdam: North-Holland, 1971. Vernon, Raymond, "International Investment and International Trade in the Product Cycle", Quarterly Journal of Economics 80 (May 1966), 190-207. 




Figure 1 


\section{$-4-$}

8217 Bade, Robin and Michael Parkin. IS STERLING M3 THE RIGHT AGGREGATE?

8218 Kosch, Bernd. FIXED PRICE EQUILIBRIA IN OPEN ECONOMIES

$\underline{1983}$

8301 Harrison, Glenn and Larry Kimbe11. ON THE SOLUTION OF GENERAL EQUILIBRIUM MODELS

8302 Melvin, James. A GENERAL EQUILIBRIUM ANALYSIS OF CANADIAN OIL POLICY

8303 Markusen, James and Lars Svensson. TRADE IN GOODS AND FACTORS WITH INTERNATIONAL DIFFERENCES IN TECHNOLOGY

8304 Mohammad, Sharif and John Whalley. RENT SEEKING IN INDIA: ITS COSTS DSU AND POLICY SIGNIFICANCE

8305 Jimenez, Emmanuel. TENURE SECURITY AND URBAN SQUATTING.

DSU

8306 Parkin, Michael. WHAT CAN MACROECONOMIC THEORY TELL US ABOUT THE WAY DEFICITS SHOULD BE MEASURED

8307 Parkin, Michael. THE INFLATION DEBATE: AN ATTEMPT TO CLEAR THE AIR

8308 Wooton, Ian. LABOUR MIGRATION IN A MODEL OF NORTH-SOUTH TRADE

8309 Deardorff, Alan V. THE DIRECTIONS OF DEVELOPING COUNTRIES TRADE: EXAMPLES FROM PURE THEORY

8310 Manning, Richard. ADVANTAGEOUS REALLOCATIONS AND MULTIPLE EQUILIBRIA: RESULTS FOR THE THREE-AGENT TRANSFER PROBLEM

8311 Mohammad, Sharif and John Whalley. CONTROLS AND THE INTERSECTORAL TERMS OF TRADE IN INDIA. 